\title{
NATURE TOURISM SATISFACTION IN OKOMU NATIONAL PARK, EDO STATE, NIGERIA
}

\author{
OGHENETEJRI DIGUN-AWETO'1, OGBANERO PIPY FAWOLE², PEET VAN DER MERWE ${ }^{1}$ \\ ${ }^{1}$ North-West University, Faculty of Economics and Business Sciences, Tourism Research in Economics, \\ Environment and Society (TREES), Potchefstroom, South Africa \\ 2 University of Ibadan, Faculty of Agriculture, Department of Agriculture and Rural Development, \\ Ibadan, Nigeria
}
Mailing address: O. Digun-Aweto, Faculty of Economic and Business Sciences, North-West University, Potchefstroom, South Africa, 2520, tel.: +27(0)18 285 2331, e-mail: 30278775@nwu.ac.za

\begin{abstract}
Introduction. This paper examines the nature tourism satisfaction of tourists visiting Okomu National Park (ONP) in Edo State, Nigeria. Material and methods. Questionnaires were randomly administered to tourists visiting the park. Factor analysis was employed to identify the major issues influencing tourist satisfaction when visiting national parks. Results. The results indicated that the majority of the tourists were youth and were first-time visitors. Furthermore, the results revealed that management, interpretation, accessibility, and expectation are the major requirements for ensuring a good experience and satisfaction when visiting national parks. Conclusion. The results of the research reveal that in order to promote tourist satisfaction, managers of national parks need to pay attention to the proper management of the flora and fauna, including the interpretation of natural features.
\end{abstract}

Key words: tourist satisfaction, national park, Okomu, Nigeria, Edo State

\section{Introduction}

In many countries, it has been found that tourism is a promising sector that deserves economic support in order to diversify such economies and work towards poverty alleviation through job creation, especially in rural areas [1, 2]. The United Nations World Tourism Organization noted that many countries have positioned their tourism sector for economic growth in order to benefit substantially, especially in sub-Saharan Africa [3]. Although Nigeria, which also falls into this category, is rich in natural and man-made tourism resources, it has failed to diversify its economy and has been unable to ensure that economic benefits of sustainable development spread to other sectors of the economy.

As a result of the country's failure to develop its potential tourism sector, it has not achieved any significant position as a tourist destination for foreign visitors. Hence, there is a need for improved techniques and management skills of stakeholders in the tourism industry. Improved data gathering is needed in Nigeria, as this will have an impact on better physical and infrastructural planning, better-targeted marketing, and a greater awareness of the benefits of tourism to the country.

In addition to federal and state governments, as well as existing tourism enterprises, other direct beneficiaries of tourism gains will be communities participating actively in tourism development. Within these communities, the direct recipients of increased income will include tour guides, handicraft producers and sellers, transportation operators, caterers, accommodation providers, and persons employed in the maintenance of community tourism facilities. Other local enterprises (particularly small shops, restaurants/bars, and farms) aiding tourism activities will also benefit from increased demand for goods and services due to enhanced spending power in local communities.
Enlisting the support of the host communities to participate is paramount for the success of ecotourism, as the members of the communities can influence the success rate of the project [4].

Tourist satisfaction gives a clear picture of the tourism product and how to improve on services provided by a tourism provider, based on the feedback received. A distinct feature that can help to improve the satisfaction of tourists can be acquired when destinations are able to meet or supersede tourists' expectations when visiting a location [5].

Nigeria is gradually striving to diversify from a mono-economy that is largely based on crude oil, but tourism still receives little attention and development. In 2006, a Tourism Master Plan for Nigeria was developed, highlighting the fact that the sector has little market information or information and statistics on tourism infrastructures nationwide [6]. The tourist products are not organized by the government but by private enterprises and individuals with little or no government support, especially in terms of the creation of an enabling environment or policies; tourist attractions are largely unknown to the international travel trade, and Nigeria's negative image within Africa and beyond has not been addressed significantly. In light of the above, tourism in Nigeria can still be regarded as being in its infant stage [6].

Okomu National Park (ONP) was created in 1991 by a federal decree of the government of Nigeria for the purpose of protecting the flora and fauna [7]. The park is the smallest of the seven national parks in Nigeria, giving the park potential to be a good destination for tourism. It has been able to attract tourists wishing to experience the rainforest vegetation and wildlife and those visiting for educational reasons. The beautiful scenery of the park, including the lakes, treehouse, Osse River, and nature trails, makes the park a worthwhile experience for both day visitors and those who stay for extended periods of time. 
Crompton and Love [8] defined satisfaction as "an emotional state of mind after exposure to the opportunity". Baker and Crompton [9] also defined satisfaction as "a tourist's emotional state after exposure to the opportunity”. The latter authors recognize that satisfaction may be influenced by the social-psychological state (e.g., mood, disposition, and needs) that a tourist brings to a site, by extraneous events (e.g., climate and social group interactions) that are beyond the provider's control, as well as by the programme or site attributes that suppliers are able to control. Understanding what makes a memorable experience for tourists can influence product development and can also have a positive impact on destination marketing. In order to understand tourist satisfaction, several researchers have employed importance-performance analysis.

Importance-performance analysis (IPA) was developed by Martilla and James [10] as a business marketing tool to evaluate and recommend business strategies. The analysis has been applied to tourism to measure visitor satisfaction and suggest management strategies for improvement [11, 12, 13]. De Nisco et al. [14] applied IPA to evaluate tourist satisfaction at one of the most attractive tourist destinations, namely Campania, Italy. They observed that IPA can be a very effective tool in helping decision-makers and major stakeholders (i.e., the experts) gather a clear understanding of the market product, and thus an understanding of what tourists' perceptions are, how to improve on areas that are lagging behind in product development, and how to improve on strong selling points.

Wade and Eagles [15] also employed IPA in a study on national parks in Tanzania, aimed at measuring visitor satisfaction, because of its ease of use when compared to SERVQUAL. For this study, the IPA was modified into a 5-point Likert scale (as opposed to the 4-point importance-performance scale), so that the analysis could give a clearer understanding of tourists' perceptions. Akama and Kieti [16] measured tourist satisfaction with safaris in Tsavo West National Park in Kenya and reported that over $70 \%$ of the tourists were satisfied with the experiences, as well as observing that the decline in tourist visits may be due to the bad access roads and security issues in Kenya. In a study on marine parks in Western Australia, Tonge and Moore [17] noted that visitor satisfaction had an influence on repeat visits to the destination and also on the recreational experiences of visitors. Another study by Tonge et al. [18] found that visitor satisfaction analysis is an important instrument to aid park managers in making decisions that help them to improve visitors' experiences.

Wei-Ching [19] examined the interrelationship between visitor perception, interpretation needs, and satisfaction with ecotourism in the Taijang National Park, Taiwan, noting that it is important for tour guides to engage with eco-tourists by means of interpretation. The findings also indicated that visitors who have a grasp of eco-tourism fundamentals are more interested in interpretation by the tour guides. The study of Van der Merwe and Saayman [20] showed that tourists' motives to visit national parks were nature, activities, attraction, nostalgia, novelty, escaping from the daily routine, and relaxation, but these factors applied to a developed market. In Nigeria, where the nature tourism market is just developing, there has to be more emphasis on the development of particular areas to ensure that nature tourism develops satisfactorily.

\section{Materials and methods}

ONP lies within the Ovia South-West Local Government Area of Edo State. The park is situated between 6015 'N and
6025'N and 509'E and 5023'E. It remains a diversity hotspot and endangered species such as the red-bellied (or white-throated) guenon/monkey (Cercopithecus erythrogaster) and forest elephants (Loxodonta cyclotis) are found here [7].

A questionnaire was used to collect data from tourists visiting the park over two periods and it was divided into two sections. Section one concerned the demographic characteristics of the respondents. Questions regarding characteristics such as age, gender, and marital status were included in this section. In the second section, statements relating to the level of satisfaction (with a list of 21 items as perceived by the tourists) were captured on a 5 -point Likert scale of importance ( 1 = not satisfied at all, 2 = not satisfied, 3 = neither satisfied nor dissatisfied, $4=$ satisfied, and 5 = very satisfied). For this research, the information that was used came mainly from the second section. This study was modelled after the work of Wade and Eagles [15] and Tonge et al. [18], but due to the limitations of the IPA, factor analysis was used to group the important factors influencing visitor satisfaction.

A site survey was done and the questionnaires were distributed among visitors at various sites in the camp. For the day tourists, the questionnaires were distributed at the assembly point when the visitors were leaving the park, which was at the park head office, whereas for the overnight tourists, who usually spend more than a day in the park, the questionnaires were administered at the chalets. The researcher, with the help of two trained assistants, approached the visitors and explained the reason for the research. They ensured that the visitors had a clear understanding of the objectives of the study before administering the questionnaires. A total of 400 questionnaires were completed over a period of six months in total over the period of two years during repeat visits.

The data was captured and analysed using SPSS version 19. First, the demographic characteristics of the tourists were profiled. Second, factor analysis was used to categorize satisfaction categories using the varimax rotation with Kaiser normalization. The Kaiser-Meyer-Olkin (KMO) measure of sampling was used to determine the measure of the adequacy of the covariance matrix suitability for factor analysis. The recommended KMO value of 0.6 or greater, as stipulated by Kaiser (1960) [21] and Bartlett's test of sphericity (1954) [22], needs a statistical significance of $\mathrm{P}=0.0000$ to ensure the adequacy of the sample for factor analysis. Items with a factor loading of 0.4 are deemed as a significant contribution to the correlation matrix.

\section{Results}

\section{Profile of visitors to Okomu National Park}

The main market visiting Okomu National Park was single persons, mainly below 40 years of age, who had at least a secondary school education. The tourists were mostly from Niger-

Table 1. Personal characteristics of respondents

\begin{tabular}{|l|l|}
\hline \multicolumn{1}{|c|}{ Category } & \multicolumn{1}{c|}{ Profile } \\
\hline Gender & Male: $58.3 \% ;$ female: $41.7 \%$ \\
\hline Marital status & Single: $64.9 \%$ \\
\hline Age & $\begin{array}{l}<20 \text { years: } 30.3 \% ; 21-30: 47.3 \% ; 31-40: 19.5 \% ; \\
\text { above } 50: 2.5 \%\end{array}$ \\
\hline Country of residence & Nigerian: $99 \% ;$ German: $0.5 \% ;$ French: $0.5 \%$ \\
\hline Level of education & At least secondary education: $93.4 \%$ \\
\hline Percentage of first visits & $100 \%$ \\
\hline
\end{tabular}


ia, with a small percentage of persons from European countries. Table 1 gives an overview of the tourist profile.

Factor analysis indicating the factors determined: nature and management, expectation, interpretation and accessibility

The factor analysis, using varimax rotation with Kaiser normalization, identified the following four factors that influence tourists' satisfaction when visiting national parks: factor 1 - nature and management, factor 2 - expectation, factor 3 - interpretation, and factor 4 - accessibility. The four factors accounted for $67.8 \%$ of the variance. A Kaizer-Meyer-Olkin measure of sample adequacy of 0.89 indicates that the correlation matrix patterns are distinctive, thus giving rise to factors. The KMO for this sample size was 0.89, which, according to Blaikie [23], is high. Bartlett's test of sphericity was significant at a p-value of 0.000 , indicating the suitability of factor analysis. Even though the factor analysis gave four distinct factors that were labelled, the factors are all interrelated with visitor satisfaction. The factors had high Cronbach alpha values, indicating good reliability and multidimensionality [24].

\section{Factor 1: Nature and management}

Factor 1 was termed "nature and park management" and is regarded as the most important factor, with the highest mean (of 3.96). It consists of constructs such as "the treehouse view was very exciting", "the rainforest view was very exciting", "the guide made my trip very interesting", "park management is satisfactory", and "the nature trails are in good shape". This factor is the first and most important factor that influences tourists' satisfaction when visiting national parks. The park has to have nature experiences that will make the tourists' visits memorable. Management of the park also plays a great role in visitors' experiences.

The viewing of wildlife is a very significant reason for visiting national parks $[25,26,27,28,29]$, which makes it imperative for management to create spots where tourists can easily view game. National parks also offer tourists natural environments that are beautiful, especially rainforest views, which can be breath-taking for visitors from urban areas. Common ecofriendly recreation facilities built around nature trails give tourists a proper feel of the rainforest views. Okello et al. [30] point-

Table 2. Factor analysis results indicating satisfaction of tourists

\begin{tabular}{|c|c|c|c|c|}
\hline Tourist satisfaction items & Nature and management & Expectation & Interpretation & Accessibility \\
\hline Mean & 3.96 & 3.69 & 3.84 & 3.56 \\
\hline Cronbach alpha & 0.94 & 0.90 & 0.86 & 0.83 \\
\hline Tree house view was exciting. & .797 & & & \\
\hline Rainforest view is very exciting. & .760 & & & \\
\hline Tree house climb was thrilling. & .755 & & & \\
\hline I was fascinated by the wilderness experience. & .708 & & & \\
\hline The guide made the trip interesting. & .706 & & & \\
\hline Park management is satisfactory. & .689 & & & \\
\hline Park accommodation was very good. & .682 & & & \\
\hline The tree house needs some maintenance. & .675 & & & \\
\hline The lakes in the park need proper management. & .625 & & & \\
\hline The chalets made my stay enjoyable. & .582 & & & \\
\hline The nature trails are in good shape. & .570 & & & \\
\hline Bird-watching experience & .482 & & & \\
\hline The chalets are in good condition. & .418 & & & \\
\hline The swimming pool was in a good condition. & & .739 & & \\
\hline The game viewing met my expectations. & & .692 & & \\
\hline The iron bridge was very fascinating. & & .683 & & \\
\hline The Osse River has beautiful scenery. & & .672 & & \\
\hline The current state of the park is satisfactory. & & .652 & & \\
\hline I was able to see a lot of park game. & & .644 & & \\
\hline The park tourist vehicles are good enough. & & .566 & & \\
\hline Water was readily available in the chalets. & & .555 & & \\
\hline The iron bridge needs management. & & & .790 & \\
\hline The iron bridge should be developed into a proper tourist site. & & & .718 & \\
\hline The nature trails need more development. & & & .644 & \\
\hline The hanging bridge needs development and maintenance. & & & .642 & \\
\hline The game in the park was easily visible. & & & & .782 \\
\hline I want to view more game. & & & & .730 \\
\hline Power supply & & & & .685 \\
\hline Jeep tracks & & & & .645 \\
\hline The roads in the park can be better managed. & & & & .472 \\
\hline
\end{tabular}


ed out that visitor satisfaction is influenced by breath-taking landscapes and beautiful scenic areas.

\section{Factor 2: Expectation}

The higher the level of satisfaction a tourist derives from an experience, the greater the chances of a repeat visit, either alone or with family and friends, or of recommending the destination to other individuals. Kim et al. [31] also corroborated these findings.

\section{Factor 3: Interpretation}

The factor labelled "the interpretation of the tourist sites" had the second-highest mean, amounting to 3.84. The large number of sites at Okomu National Park that lack proper interpretation or sufficient interpretation reduces tourist satisfaction experiences and limits the overall emotional feeling after leaving the park. This can be clearly seen when tourists are of the opinion that certain areas need more development, for example the hanging bridge, an iron bridge that is a colonial site. This site can be developed further with proper interpretation that indicates the importance of the bridge during the colonial era (when it was built), as well as the cultural and historical relevance of the bridge with regard to the colonial logging site. Good interpretation, which is essential for marketing, has a ripple effect on tourist satisfaction, as it encourages repeat visits to tourism destinations [32].

\section{Factor 4: Access}

The constructs in this factor include "jeep tracks need maintenance", "the road in the park needs maintenance", "lack of power supply in the chalets", and "I want to view more game". These comments have important implications for visitor satisfaction. For example, bad roads in the park increase the time taken to reach various destinations in the park and also reduce tourists' pleasure in driving around. A typical effect of bad roads is their adverse effect on visitors' interest in photographing birds and animals while in motion.

\section{Discussion}

The study has the following findings and implications.

The first important finding is that none of the visitors to the park had ever made a visit to it prior to the visit during which the survey was carried out. In other words, it was their first visit, implying that a large percentage of the Nigerian population have never visited a national park, nor are they very interested in nature viewing or experiencing rainforest vegetation and viewing animals in their natural habitat.

The reason may not be solely due to a lack of interest, as a lot of youth are becoming interested in outdoor and nature activities related to tourism; it may also be a lack of general awareness of a national park within the region. This fact points to the need for proper marketing strategies by park management to attract visitors, both national and international. The potential to attract tourists from the national market is enormous, seeing that Nigeria is a country with over 190 million people [33].

The second important finding for management strategy and development is that marketing should be targeted at educated individuals or persons in secondary school or higher. People should learn more about nature early on in life and develop a love for conservation for the present as well as for posterity. The findings regarding management can be linked to interpretation, which has an important implication for management, indicating that there is more need for proper interpretation in many areas of the park. This finding was mirrored by Tongue and Moore [18].

The most important factor discovered by the factor analysis pointed to nature and management, which is an indication that tourists want to experience nature first-hand and also enjoy the park's facilities, which are largely influenced by management. This is in line with the findings of Van der Merwe and Saayman [20], who opined that nature is a strong motivational factor for tourists to visit national parks.

This implies that the managers of parks need to pay attention to details in the park and ensure that facilities are in good condition because this influences satisfaction and hence repeat visits. It also has implications for word-of-mouth marketing and sharing of experiences by tourists, which, in turn, has a ripple effect on recommending the park to family and friends.

Expectation was the second most important factor derived from the factor analysis, which points to the fact that expectations are borne out of prior information or ideas tourists have about the national park. It is thus important for park management to ensure that tourists are pre-informed about the low visibility of wildlife due to the rainforest vegetation, making proper interpretation and viewing outposts imperative. Expectations not only affect repeat visits but also play a role in recommendations by visitors to their friends and family members. This was also found by Baker and Crompton [9], who noted that satisfaction has an effect on expectation, which, in turn, affects repeat visits.

The third important finding of the factor analysis was that for improved visitor satisfaction, there has to be good development and maintenance in terms of management strategies for the park and also the tourism products targeted toward visitors, which plays a role in improving their experience.

Interpretation needs proper attention due to the role it plays in making tourists' experiences more memorable and adding value through the provision of information and making the experience more satisfying. Hwang et al. [34] opined that creating interpretative spots that can double as viewing spots for wildlife makes the experiences more memorable and meaningful through practical examples.

There should be interpretation that is specifically targeted at different nature tourists; this calls for further research on tourist segmentation. For example, the park has a wide variety of species of butterflies that attract both researchers and tourists to the park, but there is no facility or designated area to aid in butterfly observation. Similarly, the management needs to develop interpretation for bird watching activities. Hwang et al. [34] also pointed out that the headquarters of national parks need to invest more in interpretation in the parks because this helps in increasing satisfaction. They observed that there should be partnerships with non-governmental organizations to help in improving and developing ecotourism products and features.

Accessibility (not only to wildlife but also in terms of getting around) is an important aspect of enhancing tourist satisfaction. It is important that visiting tourists are able to view the wildlife in the park, but with ONP being in a rainforest area, it is quite difficult to see much wildlife, which has the effect of reducing satisfaction. In a bid to improve wildlife viewing, there should be observation spots/hideouts near the lakes in the park, where elephants and buffalos have access to water. In a study on the Kruger National Park, Grünewald et al. [25] did not find any relationship between visitor numbers and large mammals visiting water holes, but rather found that natural features such as lakes and rivers had an effect on visitor numbers. This indicates that the need to create accessibility within natural confines for 
tourists without much alteration to the natural environment is an important implication for better management strategies. Moscardo and Saltzer [35] noted that being able to see large mammals or rare species of animals in their natural environment contributes towards visitor satisfaction. Kuuder et al. [36] noted that over $70 \%$ of tourists visiting the Mole National Park in Ghana were very displeased about the road conditions leading to the park, which affected satisfaction negatively.

\section{Conclusion}

This study aimed at understanding the factors determining tourists' satisfaction when visiting national parks in a bid to make their experiences memorable. The major findings of this research are important for national parks, noting that the management of the park needs constant attention and monitoring to ensure that the facilities and natural features are maintained. The most important factor influencing satisfaction is nature, which has been corroborated by the findings of Mutanga et al. [27], who observed that tourist satisfaction is influenced by a desire to be close to nature and to appreciate nature, hence the need for proper conservation of natural resources.

\section{Acknowledgments}

The authors would like to express their gratitude to the Nigerian National Parks Service, and in particular the Conservator and staff of Okomu National Park who were instrumental in completing this research. We also want to extend a heartfelt thanks to the field workers and all the respondents who took the time to complete the questionnaires.

\section{Literature}

1. Bolwell D., Weinz W. (2008). Reducing poverty through tourism. ILO Working Papers no. 994246573402676. International Labour Organization.

2. Wiggins S., Proctor S. (2001). How special are rural areas? The economic implications of location for rural development. Development Policy Review 19(4), 427-436. DOI: 10.1111/1467-7679.00142.

3. Page S.J., Hall C.M. (2014). The geography of tourism and recreation: Environment, place and space. London and New York: Routledge.

4. Kim S., Park E., Phandanouvong T. (2014). Barriers to local residents' participation in community-based tourism: Lessons from Houay Kaeng Village in Laos. SHS Web of Conferences 12, 01045. DOI: 10.1051/shsconf/20141201045.

5. Hill N., Alexander J. (2006). The handbook of customer satisfaction and loyalty measurement. London and New York: Routledge.

6. Dantata M. (2011). Tourism development in Nigeria: Challenges and prospects for resource diversification. Abuja, Nigeria: National Institute for Hospitality and Tourism.

7. Ajayi S.S. (2002). Case study 2: Multipurpose forest management for bushmeat production: A success story from West Africa. University of Ibadan, Ibadan: Department of Wildlife and Fisheries Management.

8. Crompton J.L., Love L.L. (1995). The predictive validity of alternative approaches to evaluating quality of a festival. Journal of Travel Research 34(1), 11-24. DOI: 10.1177/004728759503400102.
9. Baker D.A., Crompton J.L. (2000). Quality, satisfaction and behavioral intentions. Annals of Tourism Research 27(3), 785-804.

10. Martilla J.A. James J.C. (1977). Importance-performance analysis. Journal of Marketing 14(1), 77-79. DOI: $10.2307 / 1250495$

11. Azzopardi E., Nash R. (2013). A critical evaluation of importance-performance analysis. Tourism Management 35, 222-233. DOI: 10.1016/j.tourman.2012.07.007.

12. Chu R.K., Choi T. (2000). An importance-performance analysis of hotel selection factors in the Hong Kong hotel industry: A comparison of business and leisure travellers. Tourism Management 21(4), 363-377.

13. Ziegler J., Dearden P., Rollins R. (2012). But are tourists satisfied? Importance-performance analysis of the whale shark tourism industry on Isla Holbox, Mexico. Tourism Management 33(3), 692-701. DOI : 10.1016/j.tourman.2011.08.004.

14. De Nisco A., Riviezzo A., Napolitano M.R. (2015). An importance-performance analysis of tourist satisfaction at destination level: Evidence from Campania (Italy). European Journal of Tourism Research 10, 64.

15. Wade D.J., Eagles P.F.J. (2003). The use of importance-performance analysis and market segmentation for tourism management in parks and protected areas: An application to Tanzania's National Parks. Journal of Ecotourism 2(3), 196-212. DOI: 10.1080/14724040308668144.

16. Akama J.S., Kieti D.M. (2003). Measuring tourist satisfaction with Kenya's wildlife safari: A case study of Tsavo West National Park. Tourism Management 24(1), 73-81. DOI: 10.1016/S0261-5177(02)00044-4.

17. Tonge J., Moore S.A. (2007). Importance-satisfaction analysis for marine-park hinterlands: A Western Australian case study. Tourism Management 28(3), 768-76. DOI: 10.1016/j. tourman.2006.05.007.

18. Tonge J., Moore S.A., Taplin R. (2011). Visitor satisfaction analysis as a tool for park managers: A review and case study. Annals of Leisure Research 14(4), 289-303. DOI: 10.1080/11745398.2011.639339.

19. Wei-Ching W. (2015). Visitor perception, interpretation needs and satisfaction of eco-tourism: The case of Taijiang $\mathrm{Na}-$ tional Park, Taiwan. Enlightening Tourism 23(2), 180-200.

20. Van Der Merwe P., Saayman M., (2009). Travel motivations of tourists visiting Kruger National Park. Koedoe - African Protected Area Conservation and Science 50(1), 154159. DOI: 10.4102/koedoe.v50il.140.

21. Kaiser H.F. (1960). The application of electronic computers to factor analysis. Educational and Psychological Measurement 20(1), 141-151.

22. Bartlett M.S. (1954). A note on the multiplying factors for various chi square approximations. Journal of the Royal Statistical Society 16, 296-298.

23. Blaikie N. (2003). Analyzing quantitative data. London: SAGE Publications Ltd.

24. Shevlin M., Miles J.N.V., Davies M.N.O., Walker S. (2000). Coefficient alpha: A useful indicator of reliability? Personality and Individual Differences 28(2), 229-237. DOI: 10.1016/ S0191-8869(99)00093-8.

25. Grünewald C., Schleuning M., Böhning-Gaese K. (2016). Biodiversity, scenery and infrastructure: Factors driving wildlife tourism in an African savannah national park. Biological Conservation 201, 60-68. DOI: 10.1016/j.biocon.2016.05.036.

26. Kruger M., Saayman M. (2010). Travel motivation of tourists to Kruger and Tsitsikamma National Parks: A compara- 
tive study. South African Journal of Wildlife Research 40(1), 93-102. DOI: 10.3957/056.040.0106.

27. Mutanga C.N., Vengesayi S., Chikuta O., Muboko N., Gandiwa E. (2017). Travel motivation and tourist satisfaction with wildlife tourism experiences in Gonarezhou and Matusadona National Parks, Zimbabwe. Journal of Outdoor Recreation and Tourism 20, 1-18. DOI: 10.1016/j.jort.2017.08.001.

28. Saayman M., Saayman A. (2009). Why travel motivation and socio-demographics matter in managing a national park. Koedoe - African Protected Area Conservation and Science 51(1), 1-9. DOI: 10.4102/koedoe.v5lil.381.

29. Scholtz M., Kruger M., Saayman M. (2013). Understanding the reasons why tourists visit the Kruger National Park during a recession. Acta Commercii 13(1), 1-9. DOI: 10.4102/ ac.vl3il.168.

30. Okello M.M., Manka S.G., D’Amour D.E., (2008). The relative importance of large mammal species for tourism in Amboseli National Park, Kenya. Tourism Management 29(4), 751-760. DOI: 10.1016/j.tourman.2007.08.003

31. Kim Y.H., Duncan J.L., Jai T.M. (2014). A case study of a southern food festival: Using a cluster analysis approach. Anatolia 25(3), 457-473. DOI: 10.1080/13032917.2014.912245.
32. Tsiotsou R., Vasioti E. (2006). Satisfaction: A segmentation criterion for "short term" visitors of mountainous destinations. Journal of Travel E Tourism Marketing 20(1), 61-73. DOI: 10.1300/J073v20n01_05.

33. World Bank (2017). World development indicators. http:// datatopics.worldbank.org/world-development-indicators/

34. Hwang S.N., Lee C., Chen H.J. (2005). The relationship among tourists' involvement, place attachment and interpretation satisfaction in Taiwan's national parks. Tourism Management 26(2), 143-156. DOI: 10.1016/j.tourman.2003.11.006.

35. Moscardo G., Saltzer R. (2004). Understanding wildlife tourism markets. In K. Higginbottom (ed.), Wildlife tourism: Impacts, management and planning (pp. 167-186). Victoria, Australia: Cooperative Research Centre for Sustainable Tourism.

36. Kuuder C.J.W., Bagson E., Aalangdong O.I. (2013). Assessment of visitor satisfaction in Mole National Park, Ghana. African Journal of Hospitality, Tourism and Leisure 2(3).

Submitted: October 8, 2019

Accepted: February 7, 2020 